\title{
Technical and commercial communication methods used in semi-finished industrial goods market in South East European markets
}

\author{
Szilárd Székely ${ }^{1, *}$, Lucian-Ionel Cioca ${ }^{1}$, and Adriana Benedek $^{1}$ \\ ${ }^{1}$ Lucian Blaga University of Sibiu, Sibiu, Romania
}

\begin{abstract}
South East European industrial markets are crossing a period of strong development. This progress is also strongly felt by industrial suppliers, including semi-finished non-ferrous metal products traders. Industrial marketing presents a lot of features which differs from the consumers marketing. Analyzing these markets one can observe an increased communication between sales teams and buying centers. This communication has two major line: technical and commercial. Buying teams, which include very often engineers, need special, detailed and customized technical information related to products, delivery and payment conditions etc. The clarity and efficiency of this communication is one of the key factors of commercial success on industrial markets. In our paper we intend to analyze the communication methods, channels preferred on the mentioned markets, focusing on the interaction of personal and digital communication and other issues which are specific for industrial marketing. Research methods include: on site observations of sales teams, back office analyses of industrial suppliers' websites, professional in-depth interviews. Our goal is to deeply understand the trends and interactions of different communication methods and channels on this field and to propose new concepts in order to improve this communication.
\end{abstract}

\section{Industrial marketing 4.0}

After several years of economic crisis and decline, industrial markets from South East Europe try to reinvent and to adapt to Industry 4.0 (The Fourth Industrial Revolution), but they still have long way to reach that level. Slowly but surely digital, innovative communication solutions are spreading in the industrial marketing, too. Technical and commercial communication try to adapt new concepts, methods, and instruments. As Kotler and his partners present in Marketing 4.0 [1] the human interface, sustained by integrated digital tools and systems can be the key to success in the future for industrial marketing communication.

*Corresponding author: office@astiadvertising.ro 


\subsection{Industrial marketing 4.0 - similarities and peculiarities}

In order to study industrial semi-finished products' market first we have to make a short presentation - analyses of industrial marketing or as some call it: the business-to-business marketing (B2B). All the time industrial marketing is presented by comparing to the consumer marketing, considered by many experts or the larger public as the „classic marketing", many times as a down-graded version of it. Even if many statistics show that business markets sometimes can make larger turnovers than consumer markets. "Marketing has its roots in understanding consumers, and because we are all consumers and businessto-consumer marketing (from communication to effective selling has more visibility) it has become altogether too easy to concentrate on using consumer-based examples and theories when discussing marketing concepts. However, business markets are far larger: businesses buy and sell more goods than do consumers, and the transactions that take place between organizations have a greater impact on the economy and on the welfare of people than do the transactions between businesses and consumers." [2] First, we'll present two definitions given by two of the most recognized experts in this field. Industrial goods' marketing, as Backhaus [3] presents: „searching and exploiting the comparative competitive advantages in case of some products bought by organizations, in order to obtain higher performance". At David Ford we can feel the affiliation to IMP Group (International Marketing and Purchase Group), which has as key concept the relationship marketing. His definition of business marketing: "choosing, developing and managing the customer relations, which serves the interest of both suppliers and buyers, considering the abilities, resources, technologies, strategies and objectives of these companies".[4].

Categories of approaching of industrial marketing. Technical and commercial communication in industrial marketing is strongly influenced by the marketing approaching, most of theoretical and on field documents are based on specific approaching [5]: sales approaching, market or instrumental approach [6], interactive approach, the inside out approach (based on companies competencies, [7], relationship - networking approach (one of the most popular one in the last decades, mostly represented by IMP school, [8-10], product and business type approach [3,11], customer satisfaction approach [12] and value based approach [13-14]. These approaches have also similar aspects, but each of them is focusing on some key aspect, which in the opinion of the above mentioned experts, can create competitive advantages and superior commercial and financial results. From the above list the most frequently treated approaches are the relationship marketing, sales approach and market approach (called by some as STP strategy: segmentation, targeting and positioning). These three approaches influences the most the technical and commercial communication in industrial marketing. An important condition of successful activity on industrial markets is the proper integrating the marketing and the sales approaches. Those companies which want high sales targets, can reach them only including in a complex marketing strategy. And vice versa: a company cannot efficiently implement a marketing strategy without an efficient sales activity. In the last few decades many researcher studied the peculiarities of industrial marketing. In the following table we present a selection of these and also and adaptation to semi-finished products market, based on the works of [2, 15-20] and others.

Table 1. Industrial markets' peculiarities adaptation on the semi-finished metal products' market.

Source: [21]

\begin{tabular}{|l|l|}
\hline \multicolumn{1}{|c|}{ Industrial marketing features } & How it appears on semi-finished metal market \\
\hline $\begin{array}{l}\text { Limited number of actors, market } \\
\text { concentration }\end{array}$ & $\begin{array}{l}\text { Less than } 20 \text { important producers and less than } \\
100 \text { resellers }\end{array}$ \\
\hline Narrower customer base & $\begin{array}{l}\text { From a few dozens to a few hundreds usual } \\
\text { buyer }\end{array}$ \\
\hline
\end{tabular}




\begin{tabular}{|l|l|}
\hline Derived and inflexible demand & $\begin{array}{l}\text { Costumer market's demand influences, for ex. if } \\
\text { people don't buy cars, on medium terms } \\
\text { aluminum and steel sales decrease }\end{array}$ \\
\hline $\begin{array}{l}\text { Products are technically difficult to } \\
\text { substitute }\end{array}$ & $\begin{array}{l}\text { High quality products are important, but there are } \\
\text { no big differences between products, } \\
\text { complementary services do the difference }\end{array}$ \\
\hline $\begin{array}{l}\text { Importance of personal relations and } \\
\text { sales force }\end{array}$ & $\begin{array}{l}\text { Over } 80 \% \text { of sales are due to sales force and } \\
\text { realized with long or medium term partners }\end{array}$ \\
\hline $\begin{array}{l}\text { Many sales visit (interaction) for one } \\
\text { (first) transaction }\end{array}$ & $\begin{array}{l}\text { For the first sale sales man pays many visit and } \\
\text { changes lots of information through internet and } \\
\text { phone }\end{array}$ \\
\hline Internationally opened markets & $\begin{array}{l}\text { International and multinational corporation } \\
\text { appear on the market regularly as suppliers and } \\
\text { customers, too }\end{array}$ \\
\hline More formalized transactions & $\begin{array}{l}\text { Transactions are based on price offers (request), } \\
\text { contracts, orders, shipment documents, bank } \\
\text { payment... }\end{array}$ \\
\hline Additional services & $\begin{array}{l}\text { Cutting to size, delivery routes, packaging, } \\
\text { consultancy }\end{array}$ \\
\hline Importance of buying centers or & $\begin{array}{l}\text { Design) engineers, plant managers, buyers, } \\
\text { financial experts influence the decisions, at least } \\
\text { at major negotiations }\end{array}$ \\
\hline DMUs & $\begin{array}{l}\text { Product standards, price, reaction / delivery place } \\
\text { and time, commercial credit, brand image, } \\
\text { auxiliary services, relationship are also important }\end{array}$ \\
\hline $\begin{array}{l}\text { Many influencing } \\
\text { procurement }\end{array}$ & $\begin{array}{l}\text { The above mentioned factors are quantified and } \\
\text { weighted }\end{array}$ \\
\hline More rational decision & $\begin{array}{l}\text { In some subfields are important } \\
\text { sometimes customization needs and expectation- }\end{array}$ \\
\hline Networking -clustering & $\begin{array}{l}\text { Segmentations by size, field of activity, volume } \\
\text { of materials used, but also business style: } \\
\text { willingness to risk, need for partnership and } \\
\text { safety }\end{array}$ \\
\hline Demassification & $\begin{array}{l}\text { Those who sales electrical, aluminum, steel } \\
\text { semi-finished products don't really know in } \\
\text { which way final costumers will use the product }\end{array}$ \\
\hline Diffent segmentation & ond user info
\end{tabular}

\subsection{Trends of supplier - buyer interactions in industrial marketing 4.0}

Analyzing international procurement strategies, especially in automotive industry which is one of the main segments of our market studied in this paper, the first important issue to state is that investments are under an important pressure regarding return and growth. Piskoti [5] affirms that there are 6 major trends after international markets recovers from the economic crisis:

- $\quad$ supplier pyramids become supplier networks,

- beside outsourcing the insourcing is also increasing,

- financing becomes more and more difficult for suppliers,

- business models' differentiations is increasing,

- e-business is increasing, from euphoria to efficient implementation,

- the role of partnerships increases instead of company acquisition. 


\section{Marketing communication on industrial markets}

\subsection{New trends in industrial marketing communication}

The increased speed of sales interaction in Industry 4.0 proved that many traditional methods are no longer enough neither for buyers or suppliers. Just in time production methods demands faster communication, even if lot of technical and commercial details need to be clarified. New information and communication technologies offer new solutions for marketing and sales for industrial semi-finished markets, too. But the complexity of some of the products and transactions doesn't allow every occasion the automation of the processes. Omni-channel is the new challenge, the integration of tradition and digital marketing needs to be seamless as Kotler and partners claim in Marketing 4.0 [1].

Sales team faces new and high challenges when sales targets rapidly increase, this means a lot more personal and digital communication in less and less time, more and more decisions without enough information and time for analyses. Buyers pretend beside product and price offer also technical consultancy [22]

In nowadays industrial marketing, digital and traditional marketing concepts, instruments and tools are converging. The activity of sales forces are sustained by adapted marketing mix, digital tools and use of web based technology, strong long-term relations, automated processes, targeted communication to buying centers members, useful marketing and technical information, and customized services for key account partners. In the case of transaction type selling the interactions need to be automated as much possible, standard, but quality delivery, list prices, without discounts and no payment at term [23]. On the other hand, in case of long-term relations, with higher value of sales, selling center need to provide a more personal contact, customized services (which can be supported by business intelligence systems). Also volume and value discounts, and pay at term can increase the satisfaction of buying centers. The mutual benefits are the key to long term success. [21]

In Industry 4.0 marketing activity, including marketing communication is based more and more on hi-tech solutions (digitization and integration of vertical value chain, data and analytics as core capability, multilevel customer interaction and profiling etc.) [24].

\subsection{Target of the communication in industrial marketing}

It is vital for seller organizations to identify members of the buying center and to target and refine their messages to meet the needs of each member of the center, for example a design engineer needs information about the features of materials or semi-finished products, the production engineer about the technical description, the logistical manager about the deliveries, the financial officer about price and payment methods etc. [17].

Engineers and other staff. The communication target (mostly technical specialists, engineers) needs detailed, valuable technical information about the products (in our case semi-finished metallic products) to be able to propose the most suitable technical and economical solutions. Some of them are long term users, which have a routine approach regarding these products, while others only use these products at a project base. This influences their information demand. The first category is much easier to deal with from supplier part, most of the time asking only the actual prices and delivery conditions. In the same time, the second category, the project type users, needs more detailed information, both technical and commercial, meaning a bigger communication and back-office effort from supplier side. 


\section{Research methods and conclusions}

\subsection{Research methods}

Our research methods include:

- on site observations of sales teams, both sales representatives (sales engineers or area sales managers) and back-office teams (costumers' support managers, etc.) from steel, nonferrous metal and electrical part traders from companies mostly from Romania, but having branches, representatives or warehouses in Bulgaria, Serbia and Hungary;

- back-office qualitative and quantitative analyses of industrial suppliers' websites from industrial semi-finished non-ferrous metallic products;

- professional in-depth interviews with the above mentioned fields: sales engineers and other type of industrial sales representatives (both: operating on field and back office).

The research goal was to deeply understand the trends and interactions of different communication methods and channels on this field and to propose new concepts in order to improve the communication on the semi-finished metal markets.

We had over 20 contacts, on (sales) action observation and in-depth interviews, from sales departments from Romania, Hungary, Serbia and Bulgaria over a period of more than two years. The observed and interviewed persons where mostly engineers and economists, representing supplier companies which sales: non-ferrous metals (aluminum and copper alloys), steel semi-finished products, electrical parts etc. This was completed with participation as organizer, consultant and observer to 12 international industrial exhibition and fairs and business-to-business workshops and conferences, such as Metalshow Bucharest, Demo Metal Arad, Demo Metal Brasov, Industrial In B-to-B Meetings at Sibiu and Timisoara, etc., which all represented great opportunities to observe supplier and customer interactions from the first contact, through technical and commercial negotiation, till effective contract signing and selling.

The website's analyses were realized by direct observation of 6 major Romanian companies, non-ferrous metal suppliers which activates mostly in Romania, but also in Serbia, Bulgaria, Greece, Hungary, Bosnia and Montenegro. In order to have a quantitative and objectives approach we used Google Analytics and Woorank. Woorank is an online tool, which quantifies different SEO tools: number of backlinks to the analyzed sites, the existence of sitemap, keywords, meta descriptions, title tag, blog, social media presence, SSL (Secure Sockets Layer) security updates; also mobile compatibility, responsiveness, mobile and desktop speed etc.

From the table 2, the following: title tag, meta description, use of headings, number of pages, in-page links, existence of robots.txt, XML (eXtensible Markup Language) sitemap, mobile friendliness, backlinks, SSL are related to SEO (search engine optimization). While the others: technical data, interactive technical calculator, use of social media, and even ecommerce functions are related to technical and commercial communication. Offering services as technical on-site calculator for ex. of the theoretical weight of different shapes of different alloys increases the satisfaction of customers, eases the process of decision making and on the other side increases the efficiency of sales process of supplier companies.

An important aspect of the research revealed that one of the most urgent issue in business-to-business technical and commercial communication is the lack of time due to increased sales target and of the complexity. Sales persons have less and less time to offer the proper information, only an effective, innovative use of new technology can improve the situation, but without neglecting the human aspects. 
Table 2. Synthesis of analyses of websites and online communication of major Romanian non-ferrous metal traders which activates in Romania, Hungary, Serbia, Macedonia, Greece and Bulgaria using on-sites observation and Woorank analyses

\begin{tabular}{|c|c|c|c|c|c|c|}
\hline Company & Comp A & Comp B & Comp C & Comp D & Comp E & Comp F \\
\hline Technical data & Detailed & Yes & Yes & No & No & No \\
\hline $\begin{array}{c}\text { Interactive } \\
\text { calculator }\end{array}$ & Yes & No & Yes & No & No & No \\
\hline E-commerce & Partial & No & No & No & Partial & No \\
\hline SEO Score & 60 & 46 & 45 & 27 & 48 & 50 \\
\hline Title tag & Yes/58Char & Yes/20Char & Yes/61Char & Yes/61Char & Yes/21Char & Yes/7char \\
\hline Meta descr & Yes/167Char & Missing & Yes/192Char & Yes/6 char & Yes/208 Char & Yes/75 Char \\
\hline Headings & H2-11,H3-5 & H1-2, H2-3 & H1-6, H3-1 & H1-1, H2-2 & H3-8 & H1-1, H2-3 \\
\hline Pages & 4653 & 549 & 186757 & 375 & 128 & 199 \\
\hline In-Pag links & 77 & 52 & 89 & 23 & 7 & 25 \\
\hline Robosts.txt & Yes & Yes & Yes & No & Yes & Yes \\
\hline XML Sitemap & & No! & No! & No! & No! & No! \\
\hline Mobile & Yes & Yes & No & No & Yes & Yes \\
\hline Ganalytics & Yes & Yes & Yes & No & No & Yes \\
\hline SSL & Yes & Yes & No & No & Yes & No \\
\hline Backlinks & 6672 & 284 & 1777 & 5051 & 28 & 181 \\
\hline Facebook & Yes & No! & No & No & No & No \\
\hline Twitter & Yes & Yes & Yes & No & Yes & No \\
\hline Blog & No & No & No & No & No & No \\
\hline Trafik Rank & 166985 & 17376320 & 3356446 & No & 10282457 & 11468769 \\
\hline
\end{tabular}

Other aspects revealed from the research is the delay of using new technology among companies from these subdomains, while some companies already implement second or newer generation of ERP systems, others still use only phone-calls and faxes for product orders. Some companies have different hi-tech IT tools, but those are not properly harmonized in a single eco-system. For example they have an ERP (Enterprise-ResourcePlanning) system, but the transition of data from ERP to sales applications are not seamless. Also, upgrading and keeping data bases up-to-date is a difficult and expensive task. Day by day activity with customers is the most urgent task of sales persons and this is why they sometimes neglect updating.

\subsection{Technical and commercial communication channels and methods}

In the last few decades, due to the development of information and communication technologies, the sales and marketing communication channels also became more diversified and complex. Traditional, personal marketing channels coexist with e-business solutions. Even more these channels are converging now, creating the omni-channel [1]. These trends influenced the behavior of both supplier and buyer side, and normally all the interactions between them. Globalization, change of international markets also contributes to these effects. [5]. 
"The Internet and related technologies have had a profound impact on the way in which organizations communicate with each other. However, this is not to suggest that the influence of the traditional offline communication tools has waned, indeed it can be argued that marketing communications have been augmented by the application of new technologies." [17] Traditionally the main marketing communication tools were: advertising, sales promotion, public relations, direct marketing and personal selling. Nowadays, due to technological development, these tools changed and also other tools appeared. Kotler and co. [1] affirmation can be shocking at the first reading:" content is the new Ad, \#hashtag is the new tagline". Also emphasis on the importance of (social) CRM (customer relationship management), mobile apps and gamification. Online marketing experts agree with the affirmation regarding the importance of (online) content in industrial marketing, too [25].

Many marketing or sales managers affirm, that they have to be present wherever their customers are present, for buying or looking for technical or commercial information. [5]. This "wherever" could mean based on our research (in-depth professional interviews): personal visit, phone calls, exhibition meeting, technical magazines or revues, B2B workshops - events, but also online presence. Being simply present online (having a webpage, a social media page etc.) it is not enough anymore, your company needs to be easy to access through search engines. If a company's page is on the first page of Google search, means that they "exist", if not they have serious handicap.

Industrial exhibitions have a long and successful history in business-to-business marketing. Even if in the last 20 years some critics appeared regarding these events, they can still pay an important role [26]. Norman Hart emphasizes a positive aspect of exhibitions: "potential customers pay visits to your stand, and not vice versa, visitors show more perceptiveness, refusal is more difficult" [27]. According to the EIF Exhibition Industry Federation, exhibitions are visited mostly (over $80 \%$ ) by the right persons, meaning the persons that companies with stands waits, persons included in the profile of "influencer", from the groups which takes decisions in industrial acquisitions. The main functions of fairs: increasing of commercial trades, increasing of technical and commercial information exchange, motivating visitors, promotion (image promoting and increasing attention towards new products). [16, 19, 28].

A research realized by Médianéző in Hungary in 2014 related to business-to-business companies' spending with communication channels shows the increased importance of personal communication and digital communication in the detriment of traditional advertising[5].

Use of web based technology - online technical and commercial communication, proper customer data base, CRM systems, EDI (Electronic Data Interchange) or ERP systems, B2B adapted e-commerce platforms, segmented and targeted newsletter communication etc. also increase the quality of supplier response to I.P.B. (Industrial Procurement Behavior) [21] One of the first tools needs to be the use of search engine optimized web pages (for giving permission to customers to obtain information and contact suppliers), which are also filled up with valuable technical and commercial information and user friendly. Acquiring valuable data about customers and properly managing them (including CRM, ERP and on medium term big-data use) can increase the value of services provided to customers. A supplier needs to be everywhere where a (potential) customers is looking for information, products, services, advices [25, 29]. Organizations need to be sure that strategic relationships between suppliers and customers are protected and technology is used to complete long term partnership, not to jeopardize them [17]. 


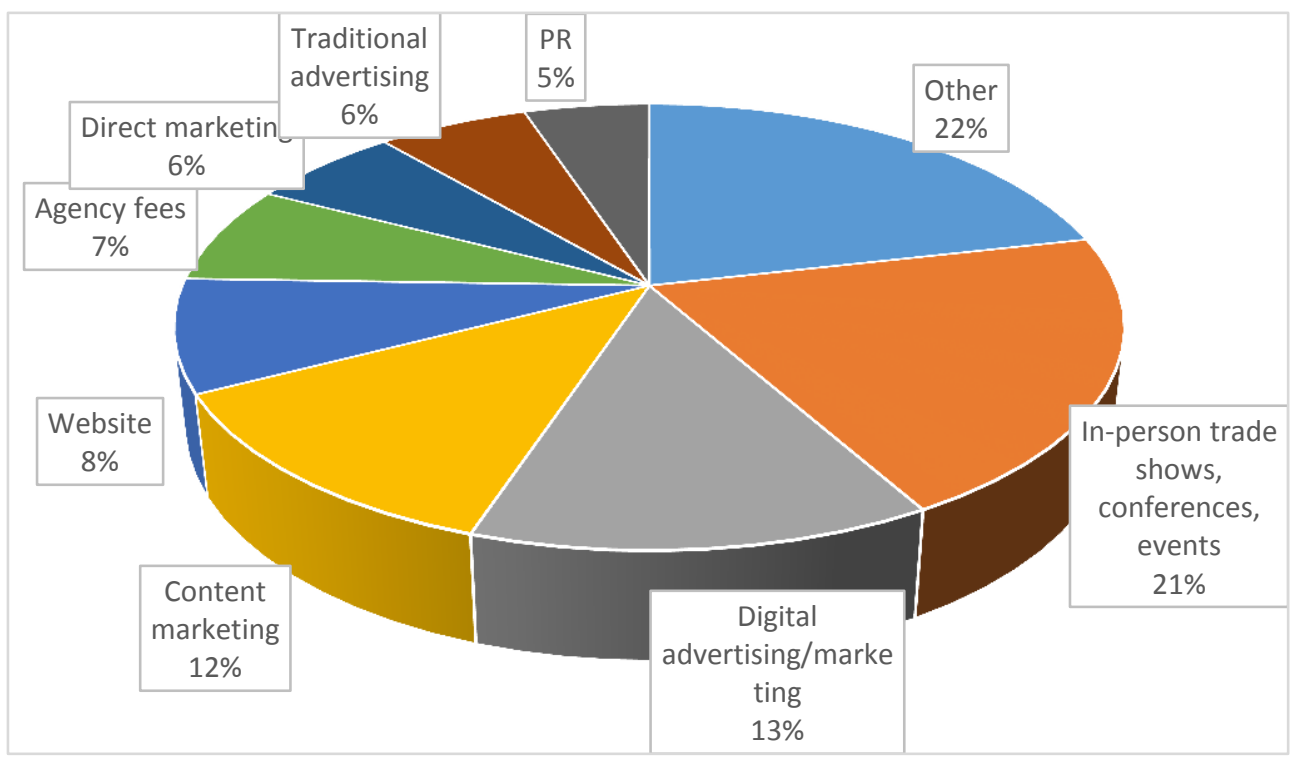

Fig.1 Business-to-business companies' spending with communication channels in Hungary. Source: [5]

And finally, as Kotler [1] suggested "technology convergence will ultimately lead to the convergence between digital marketing and traditional marketing. In a high-tech world, people long for high touch". So, the same on the metal semi-finished products market, supplier needs to develop strong relationships with buyers using the personal high quality touch of sales force and also back-up from online (digital) technology. But regarding also the efficiency of serving markets sales force needs to focus personally on long term relations and key accounts while transaction type sales need to be automated. So, I propose a model with proportioned use of personal selling, the more important the customer and the relations are, the more personal involvement and customized services are necessary for a quality response to customers' needs.

\section{References}

1. Ph. Kotler, H. Kartajaya, I. Setiawan, Marketing 4.0 -Moving from Traditional to Digital, (Wiley, N.J., USA, 2017)

2. A. Zimmerman, J. Blythe, Business to business marketing management a global perspective, (II. Edition Routledge Taylor and Francis Group, New York, USA, 2013)

3. K. Backhaus, Industriegutermarketing, 7. Aufl., Vahlen Verlag, Munchen, (2001)

4. D. Ford, Business Marketing, (Editura KJK Kerszov, Budapesta, 2003)

5. I. Piskóti, Businessmarketing-menedzsment - Üzleti döntések, kapcsolatok marketingtámogatása, (Ed. Akadémiai, Budapesta, 2014)

6. K. Backhaus, K. Lügger, M. Koch, Industrial Marketing Management, 40, 6, pp.940-951 (2011)

7. C.K. Prahalad, G. Hamel, HBR , 68, 3, pp. 79-91 (1990)

8. D. Ford, Industrial Marketing Management, 13, 2, pp.101-112 (1984)

9. M.T. Cunningham, EJM, 14, 5/6, pp.322-338 (1980)

10. Borders, A.L., Johnston, W.J. and Rigdon, E.E. Industrial Marketing Management, 30, 2, pp.199-205 (2001)

11. M. Kleinaltenkamp, W. Plinke, Geschaftsbeziehungsmanagement, (Springer Vg., 1985)

12. M. Bruhn, Kundenorienterung, (Deutschen Taschenbuch Verlag, Munchen, 2007)

13. J.C. Anderson, J.A. Narus, Business Market Management: Understanding, Creting and Delivering Value. (Prentice Hall, Pearson, 2004) 
14. P. Kothandaraman, D Wilson, Industrial Marketing Management, 30, 4, pp.379-89 (2001)

15. M. Torocsik, Vasarloi magatartas, (Editura Akademiai, Budapesta, 2007)

16. M. Torocsik, Ipari marketing, (Editura Nemzeti Tankonyvkiado, Budapesta, 1996).

17. C. Fill, Business to business marketing, relationships, systems and communications, (Pearson Ed. Ltd, UK, 2005)

18. Ch. Grönroos, JBIM, 19, 2, pp.99-113 (2004)

19. L. Jozsa, I. Piskoti, G. Rekettye, Z. Veres, Decision oriented marketing, (Editura KJK Kerszov Budapest, 2005).

20. Kotler, Ph., Keller K.L., Marketing Menedzsment 12th Edition, (Akademiai Kiado, Budapest, 2006)

21. Sz. Székely, A. Benedek, L.I. Cioca, Quality Supplier Response to Industrial Procurement Behavior on the South East European Metal Distribution Market, SIMPRO Conference Petrosani, (2018)

22. L. Ivascu, B. Cirjaliu, A. Draghici, 3rd Global Conference on Business, Economics, Management and Tourism (BEMTUR), Procedia Economics and Finance, 39, pp.674-678 (2015)

23. M. Izvercian, A. Radu, L. Ivașcu, Ben-Oni Ardelean 12th International Symposium in Management, Timișoara, Procedia - Social and Behavioral Sciences, 124, pp.27-33 (2013)

24. Price Waterhouse Cooper: Industry 4.0: Building the digital enterprise (2016)

25. V. Fox, Marketing in the age of Google, (John Wiley and Sons inc., New Jersey, USA, 2010)

26. Sz. Székely, A. Benedek, L.I. Cioca, RMEE Conference, Cluj-Napoca (2018)

27. N. Hart, Marketing Industrial, (Editura Codecs, București, 1998)

28. M., Gomes, T., Fernandes, A., Brandao, JBIM, 31, 2, pp.193-204 (2016)

29. S. Ransbotham, D. Kiron, Using Analytics to Improve Customer Engagement, MIT Sloan Management Review (2018) 